\title{
Upaya Meningkatkan Minat dan Kemampuan Kognitif Siswa SMK Melalui Waze Apps
}

\author{
Hijrah Syahputra
}

SMK Negeri 3 Gorontalo

Email: hijrah.syahputra@gmail.com

\begin{abstract}
ABSTRAK
Tujuan penelitian ini adalah meningkatkan kualitas pengajaran dan menggunakan perangkat lunak Waze pada mata pelajaran Mekanika Teknik di antara SMK Negeri 3 Gorontalo, kelas X TP-2. Penelitian ini menggunakan metode penelitian tindakan kelas, yang terdiri dari dua siklus. Setiap siklus: (1) rencana; (2) menerapkan; (3) bertindak mengamati; dan (4) mencerminkan. Penelitian ini menggunakan perangkat lunak Waze dalam strategi pembelajaran penemuan. Data dikumpulkan dari observasi, kuesioner, dan tes kertas. Penelitian ini telah mengungkapkan bahwa, ada peningkatan minat belajar dan keterampilan kognitif siswa. Berdasarkan temuan ini, maka direkomendasikan bahwa Guru Mekanika Teknik harus didorong untuk menggunakan perangkat lunak Waze di internet untuk instruksi yang efektif dari materi pelajaran Mekanika Teknik.
\end{abstract}

Kata kunci: waze; penyelidikan; pembelajaran penemuan; mekanis

\section{ABSTRACT}

The aim research is icreased instruction quality and utilized Waze software on Mekanika Teknik subject matter amongst SMK Negeri 3 Gorontalo, XTP-2 grade. This research used classroom action research method, consisting of two cycles. Each cycles: (1) plan; (2) implement; (3) act observe; and (4) reflect. This research utilized Waze software in discovery learning strategy. Data collected from observation, questionnaire, and paper test. This research has revealed that, there were enhancement in the learning interest and cognitive skill of student. Based on these findings, it was therefore recommended that Mekanika Teknik Teacher should be encouraged to use Waze software on internet for effective instruction of Mekanika Teknik subject matter.

Key words : waze; inquiry; discovery learning;mechanical

(C) 2019 Hijrah Syahputra Under The License CC-BY SA 4.0

\section{PENDAHULUAN}

Sekolah Menengah Kejuruan (SMK) diharapkan memfasilitasi peserta didik agar kelak mampu bersaing dengan bekal keterampilan yang memadai. Pembelajaran di sekolah kejuruan dilaksanakan dengan cara merealisasikan teori-teori dasar yang relevan kedalam kerja praktek yang diatur sedemikian rupa. Proses kerja praktek baik di sekolah maupun di industri akan meningkatkan kualitas pengalaman belajar peserta didik guna mencapai tujuan terselenggaranya pendidikan di SMK.

Kurikulum 2013 memberikan garis dalam proses pembelajaran, yakni pendekatan santifik. Pendekatan saintifik 


\section{PEDAGOGIKA}

\section{Volume 10 (Nomor 2) 2019}

Hal. 72-83

merupakan penerapan prinsip-prinsip ilmiah kedalam proses pembelajaran. Pendekatan saintifik mendorong peserta didik untuk menjelaskan secara logik terhadap fenomena pembelajaran yang dihadapinya. Selain itu, peserta didik didorong untuk berpikir kritis, analitis, dan sistematis. Langkah-langkah kegiatan pembelajaran dengan pendekatan saintifik terdiri dari 5 langkah, yakni: (1) mengamati;

(2) menanya;

mengumpulkan informasi; (4) mengasosiasi; dan (5) mengkomunikasikan (Direktorat PSMK, 2013).

Kegiatan mengamati bertujuan untuk mengaitkan konteks situasi nyata dalam kehidupan sehari-hari dengan pembelajaran. Menanya merupakan proses pembangunan pengetahuan peserta didik dalam bentuk konsep, prinsip, prosedur, hukum, dan teori, hingga berpikir metakognitif. Kegiatan mengumpulkan informasi dapat meningkatkan keingintahuan peserta didik untuk memperkuat pemahaman konsep/ prosedur. Mengasosiasikan bertujuan untuk membangun membangun kemampuan berpikir dan bersikap ilmiah. Kegiatan mengkomunikasikan dilakukan agar peserta didik mampu menyampaikan hasil konseptualiasi dalam bentuk lisan, tulisan, gambar/ sketsa, diagram, atau grafik.

Proses pembelajaran yang ideal mampu memberikan kesempatan kepada peserta didik untuk berkembang secara mandiri, baik dalam hal sikap spiritual, sosial, pengetahuan, dan keterampilan. Proses pembelajaran yang memanfaatkan berbagai macam sumber belajar dapat menghindari proses pembelajaran yang monoton. Proses pembelajaran hendaknya dilakukan secara holislik, sehingga juga melahirkan peserta didik yang berkualitas secara utuh. Paling tidak, proses pembelajaran di SMK mampu menerapkan prinsip inquiry, pembelajaran berbasis aneka sumber, mengedepankan keterampilan aplikatif, pemanfaatan teknologi informasi dan komunikasi untuk meningkatkan efesiensi dan efektivitas pembelajaran, dan perbedaan individu (Kementerian Pendidikan dan Kebudayaan RI, 2013).

Kurikulum 2013 memilih proses saintifik sebagai pendekatan dalam proses belajar di kelas. Tujuan ditetapkannya pendekatan saintifik dalam pembelajaran adalah guru dituntut untuk mengeluarkan segenap daya, pikiran, dan upaya agar peserta didik aktif dalam belajar. Informasi pengetahuan yang diterima mampu dikembangkan sendiri oleh peserta didik. Secara sederhana pembelajaran hendaknya mengedapankan proses pemerolehan informasi oleh peserta didik melalui kegiatan observasi/ eksperimen untuk memecahkan pertanyaan yang dimunculkan.

Proses melakukan observasi, ketika peserta didik bereksperimen, hingga sampai pada pengambilan kesimpulan dan mengkomunikasikannya kepada temantemannya atau gurunya, merupakan suatu gambaran ideal yang diharapkan terjadi di kelas. Peserta didik terlibat aktif dari awal hingga akhir dalam proses pembelajaran. Hal tersebut sesuai dengan apa yang dikatakan oleh Sotjipto (2001) bahwa proses inquiry yang diterapkan dalam pembelajaran merupakan penerapan dari konsep active learning.

Penerapan metode inquiri dapat dibantu menggunakan teknologi . Pemanfaatan teknologi memberikan warna baru dalam proses pendidikan di sekolah. Teknologi dalam pembelajaran di kelas 


\section{PEDAGOGIKA}

\section{Volume 10 (Nomor 2) 2019}

Hal. 72-83

memberikan harapan kepada peserta didik untuk memperoleh hasil belajar yang lebih baik dibandingkan dengan pembelajaran tradisional/ metode ceramah (Roblyer \& Doering, 2013). Akan tetapi, tidak semua berjalan efektif dalam pembelajaran. Pendidik harus selektif dalam menentukan jenis sumber daya pembelajaran yang akan digunakan. Pemilihan jenis teknologi, jenis peranti lunak, dan jenis konten materi yang tepat sangat menentukan kualitas belajar dan motivasi siswa (Smaldino, Lowther, \& Russel, 2012).

Fenomena perangkat lunak yang berkembang pesat akhir-akhir ini memberikan kemudahan kepada setiap orang dalam kehidupan sehari-hari. Keniscayaan tersebut berubah menjadi sebuah kebutuhan, bahkan cenderung menjadi ketergantungan. Fenomena tersebut harus dimanfaatkan semaksimal mungkin dalam membantu perkembangan diri seseorang dalam berbagai hal, tanpa terkecuali dalam dunia pendidikan. Pembelajaran yang memafaatkan sebuah aplikasi/ software yang dapat dijalankan oleh teknologi dapat dijadikan sebuah upaya untuk menjembatani proses pengalaman belajar peserta didik, sehingga menjadi lebih dinamis, menyenangkan dan pada akhirnya melahirkan suatu pembelajaran yang efektif. Pembelajaran hanya dengan menggunakan metode ceramah memiliki keterbatasan visualisasi yang ingin ditangkap oleh peserta didik. Proses pembelajaran terjadi secara 1 arah, karena didominasi oleh instruksi guru. Akibatnya peserta didik menjadi pasif. Pasif dalam mengembangkan informasi yang diperolehnya. Keyataan ini, memberikan kesulitan kepada peserta didik untuk mengembangkan pengetahuannya sendiri guna dimanfaatkan untuk meningkatkan kualitas keterampilan aplikatifnya.

Pembelajaran Mekanika Teknik meliputi konsep-konsep dasar tentang teknik mesin. Mekanika Teknik menjadi mata pelajaran dasar kejuruan yang amat penting dalam menentukan kualitas pembelajaran pada tahapan yang lebih tinggi. Tantangan menjadi lebih berat yang harus dihadapi oleh pendidik di SMK ketika kondisi kemampuan kognitif peserta didik sangat lemah. Hal tersebut tercatat dalam studi yang dilaksanakan oleh Trends in International Mathematics and Science Study (TIMSS) pada tahun 2015. Tercatat bahwa kemampuan bernalar siswa Indonesia berada pada rerata 20 dari 44 pada Matemaika, dan 26 dari 44 pada IPA. Rerata persentase jawaban benar siswa Indonesia dibandingkan dengan negara Internasional pada konten Paparan data adalah 31 dari 57, dan tentang Ilmu Fisika berada pada angka 32 dari 48 (Kemendibud, 2016).

Lebih lanjut, berdasarkan catatan guru mata pelajaran Mekanika Teknik dari tahun pelajaran 2014/2015 sampai 2015/2016 terdapat rata-rata 3 dari 10 peserta didik membutuhkan remedial (SMK N 3 Gorontalo, 2016). Selain itu, terdapat keluhan guru ketika proses pembelajaran Mekanika Teknik yang menyebutkan bahwa siswa cenderung pasif, mengobrol, dan merasa bosan saat pembelajaran berlangsung.

Menjadi tanggung jawab pendidik untuk membantu memecahkan permasalahan pendidikan di Indonesia. Dimana tingkat motivasi belajar peserta didik yang berhubungan dengan kemampuan matematika terbilang rendah. Hal tersebut dapat dilihat dari data TIMSS yang 


\section{PEDAGOGIKA}

\section{Volume 10 (Nomor 2) 2019}

Hal. 72-83

menyebutkan bahwa Hanya $27 \%$ orang tua di Indonesia melakukan kegiatan yang menstimulus kemampuan numerasi dan literasi siswa, sementara rerata Internasionalnya 44\% (Kemendibud, 2016). Orang tua Indonesia jarang melakukan kegiatan bersama anaknya, seperti mendongeng, menyanyikan lagu alfabet, dan kegiatan lainnya yang menyengkan yang diyakini berpengaruh terhadap kemampuan matematika anak.

Pendidik perlu mencari strategi yang terbaik untuk memperbaiki kondisi kondisi belajar siswa. Salah satu caranya adalah dengan menerapkan pembelajaran inquiri. Pembelajaran inquiri mampu meningkatkan prosentase motivasi belajar peserta didik kelas 7 rata-rata $10,67 \%$ (Marfungatun, 2012). Penerapan metode inquiri di kelas banyak ragamnya. Jika dikaitkan dengan perkembangan teknologi metode inquiri dapat dilaksanakan dengan memanfaatkan perangkat lunak/ software yang dapat diakses secara free.

Perangkat lunak/ software yang dapat digunakan dalam pembelajaran Mekanika Teknik adalah aplikasi Waze. Aplikasi Waze dapat diakses dengan mudah oleh pendidik maupun peserta didik. Kondisi perkembangan teknologi mendukung peserta didik dan pendidik untuk mengakses aplikasi Waze dengan mudah.

Hadirnya aplikasi Waze dalam perkembangan teknologi komputer, memberikan warna baru dalam penerapan metode inquiri dalam pembelajaran Mekanika Teknik. Aplikasi Waze merupakan aplikasi komunitas untuk saling berbagi informasi tentang kondisi lalu lintas dan aplikasi navigasi (Waze, 2016).

\section{Pembelajaran Mekanika Teknik}

Mata pelajaran Mekanika Teknik merupakan salah satu cabang ilmu fisika. Pembelajaran mekanika teknik menitikberatkan pada meningkatkan kemampuan peserta didik dalam memahami seluk beluk tentang gerak mekanis yang terjadi pada pemesinan. Teknik pemesinan itu sendiri berkaitan dengan keterampilan motorik gerak siswa dalam mengoperasikan mesin-mesin perkakas dan alat-alat yang berkaitan dengan mesin tersebut. Teknik pemesinan juga menantang peserta didik untuk mengeluarkan kemampuannya dalam mengaitkan konsep-konsep dasar ilmu mekanika dengan ilmu keterampilan pemesinan.

Mata pelajaran Mekanika Teknik memuat beberapa kompetensi dasar. Kurikulum 2013 menetapkan 13 kompetensi dasar yang harus dikuasai oleh peserta didik. Salah satu kompetensi dasar yang menjadi tujuan dalam penelitian ini adalah tentang besaran skalar, besaran vektor, sistem satuan, dan hukum newton (Kemendikbud, 2016).

Besaran skalar dan besaran vektor merupakan hasil pengukuran yang dinyatakan dalam angka. Perbedaan besaran skalar dengan besaran vektor adalah pada sifat angka yang dinyatakan. Besaran skalar merupakan besaran yang hanya memiliki besar atau nilai saja, contoh : 5 meter, $40^{\circ} \mathrm{C}$, $3 \mathrm{~kg}$. Sedangkan besaran vektor merupakan besaran yang menunjukan besar atau nilai dan mempunyai arah, contoh : $60 \mathrm{Km} / \mathrm{h}, 9,81$ $\mathrm{m} / \mathrm{s}^{2}$. Simbol yang mengikuti angka pada hasil pengukuran disebut dengan satuan. Pada hasil pengukuran harus dinyatakan dengan besaran dan satuan untuk memperjelas identitas obyek yang diukur. Dengan kata lain, satuan merupakan 


\section{PEDAGOGIKA}

\section{Volume 10 (Nomor 2) 2019}

Hal. 72-83

perbandingan antara besaran yang diukur dengan besaran yang sejenis (Widiyanto \& Yogaswara, 2013).

Mekanika teknik dalam pemesinan juga mempelajari tentang hukum Newton. Hukum Newton menjelaskan konsep-konsep tentang benda/ materi yang bergerak atau dalam keadaan diam (Berpendidikan, 2015). Hukum Newton 1 menyatakan bahwa "Jika resultan gaya yang bekerja pada benda yang sama dengan nol, maka benda yang mulamula diam akan tetap diam. Benda yang mula-mula bergerak lurus beraturan akan tetap lurus beraturan dengan kecepatan tetap“.

$$
\begin{gathered}
\sum \mathbf{F}=\mathbf{0} \\
\text { Atau, Resultan gaya }\left(\mathrm{Kg} \mathrm{m} / \mathrm{s}^{2}\right)
\end{gathered}
$$

Bunyi Hukum Newton 2 adalah "Percepatan sebuah benda berbanding lurus dengan gaya total yang bekerja padanya dan berbanding terbalik dengan massanya. Arah percepatan sama dengan arah gaya total yang bekerja padanya".

$$
\begin{aligned}
& \qquad \sum \mathbf{F}=\mathbf{m} \mathbf{X} \text { a } \\
& \text { Dengan, } \\
& \mathrm{F}=\text { gaya }(\mathrm{N}) \\
& \mathrm{m}=\text { massa benda }(\mathrm{Kg}) \\
& \mathrm{a}=\text { percepatan }\left(\mathrm{m} / \mathrm{s}^{2}\right) \\
& \text { Hukum Newton } 3 \text { berbunyi "Setiap }
\end{aligned}
$$
aksi akan menimbulkan reaksi, jika suatu benda memberikan gaya pada benda yang lain maka benda yang terkena gaya akan memberikan gaya yang besarnya sama dengan gaya yang diterima dari benda pertama, tetapi arahnya berlawanan“.

\section{$\mathbf{F}_{\text {aksi }}=-\mathbf{F}_{\text {reaksi }}$}

Hasil belajar memiliki beragam bentuk yang dapat diamati, tetapi terdapat hal yang paling penting untuk mencapai hasil belajar yang bermakna, yaitu kemampuan siswa untuk mengingat, kemampuan memahami, dan kemampuan menggunakan apa yang sudah dipelajari (Anderson \& Krathwohl, 2010). Mengingat atau mengetahui tentang pengetahuan tertentu dan mampu mengembangkan kemampuan intelektual serta keterampilan berpikir merupakan tujuan pendidikan yang menurut Bloom termasuk dalam kawasan kognitif. Dimensi proses kognitif menurut Bloom yang telah direvisi oleh Anderson dan Krathwohl meliputi enam kategori, yaitu: (1) mengingat; (2) memahami; mengaplikasikan; (4) menganalisis; (5) mengevaluasi; dan (6) mencipta. Keenam kategori tersebut bersifat hierarkis, dimulai dari jenjang yang paling sederhana yaitu mengingat hingga ke jenjang yang lebih kompleks yaitu mencipta.

Penetapan perencanaan pembelajaran mekanika teknik perlu diidentifikasi dan dianalisis karakterisitk peserta didik. Pemahaman karakteristik peserta didik sangat diperlukan untuk memurtuskan metode apa yang sesuai untuk diterapkan dalam pembelajaran. Peserta didik di tingkat SMK jika dilihat dari proses perkembangan intelektualnya menurut Piaget berada pada tahap operasi (kegiatan-kegiatan mental tentang berbagai gagasan) formal (Crain, 2007). Cara berpikir peserta didik dalam masa remaja berkaitan dengan dunia kemungkinan/ peluang dalam mencapai keinginannya. Pada masa remaja peserta didik sudah memiliki kemampuan dalam membedakan sesuatu yang nyata dan konkrit dengan yang abstrak dan mungkin. Kemampuan dalam membuat perencanaan untuk mencapai segala kemungkinan yang menjadi tujuannya, dan kemampuan mengeksplorasi berbagai kemungkinan yang 


\section{PEDAGOGIKA}

\section{Volume 10 (Nomor 2) 2019}

\section{Hal. 72-83}

menjadi tujuannya, dapat dijadikan modal untuk mengembangkan cara belajar dalam pembelajaran mekanika teknik.

\section{Aplikasi Waze dalam Pembelajaran}

Aplikasi Waze merupakan aplikasi komunitas berbasis lalu lintas dan aplikasi navigasi terbesar di dunia (Waze, 2016). Membuka aplikasi Waze maka pengguna dapat bergabung dengan pengendara lainnya di area tertentu yang berbagi tentang kondisi lalu lintas secara langsung dan info jalan. Jika pengguna dapat memanfaatkan informasi untuk mengetahui kondisi jalur yang akan dilewati, maka pengguna jalan dapat menghemat waktu dan biaya bahan bakar. Selain itu, aplikasi Waze memiliki tampilan yang unik dan menarik sehingga tidak membosankan untuk dilihat.

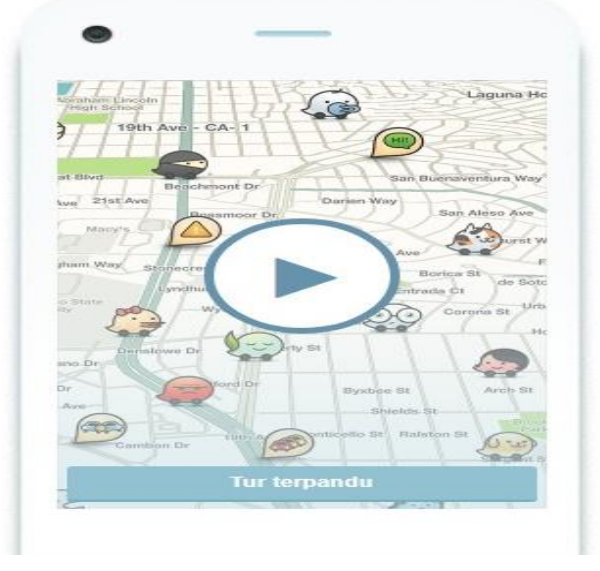

\section{Gambar 1 Tampilan Waze}

Kegiatan pembelajaran mekanika teknik menuntut kemampuan analasis dan sikap kritis peserta didik. Aplikasi Waze dapat membantu pendidik untuk memfasilitasi siswa dalam mengembangkan tujuan pembelajaran mekanika teknik. Aplikasi/ perangkat lunak Waze merupakan salah satu penerapan metode discovery dengan pendekatan induktif atau inquiri. Peserta didik yang memperoleh pengalaman belajar melalui kegiatan-kegiatan yang direncanakan berpotensi lebih baik dibandingkan dengan mendengar dan membaca tentang konsep (Newby \& et., al., 2011).

Memanfaatkan Waze berarti menempatan peserta didik pada situasi belajar yang menyenangkan. Peserta didik belajar melalui pengalamannya sendiri, contoh: melakukan observasi dan komparasi/ membandingkan, seperti bermain peran sebagai detektif yang sedang mempelajari petunjuk-petunjuk dan temuan-temuan yang diperoleh. Kemudian menjelaskan apa yang mereka alami/ peroleh dari kegiatan tersebut.

Peserta didik akan memperoleh pemahaman yang mendalam dari suatu pokok bahasan memalui keterlibatan aktif. Aplikasi Waze memungkinkan peserta didik untuk menemukan jawaban dari masalah yang diajukan. Sehingga pada akhirnya peserta didik menjadi lebih termotivasi untuk belajar. Pertama-tama pendidik mengajukan masalah, dilanjutkan dengan kegiatan pemecahan masalah oleh peserta didik melalui kegiatan trial and error (coba-coba). Urutan pembelajaran discovery dengan memanfaatkan software Waze adalah: (1) 


\section{PEDAGOGIKA}

\section{Volume 10 (Nomor 2) 2019}

Hal. 72-83

stimulation; (2) problem statement; (3) data collecting; (4) verification; dan (5) generalization (Pido, 2010).

Berdasarkan uraian di atas, penulis tertarik untuk meneliti tentang pemanfaatan aplikasi Waze dalam pembelajaran Mekanika Teknik di Teknik Pemesinan SMK Negeri 3 Gorontalo.

\section{METODE PENELITIAN}

Penelitian ini merupakan penelitian tindakan kelas. Penelitian ini menggunakan model Kemmis and McTaggart. Model Kemmis and Taggart merupakan model siklus penelitian tindakan yang dikembangkan dari model Kurt Lewin yang kemudian disesuaikan dengan beberapa perkembangan. Model Kemmis and Taggart terdiri dari 4 tahapan, yaitu: (1) perencanaan; (2) tindakan; (3) observasi; dan (4) refleksi.

Subjek penelitian ini adalah peserta didik kelas $\mathrm{X}$ TP-2 tahun pelajaran 2016/2017. Jumlah subjek penelitian adalah 26 orang. Seluruhnya berjenis kelamin lakilaki. Subjek penelitian merupakan peserta didik yang terdaftar dalam Kompetensi Keahlian Teknik Pemesinan SMK Negeri 3 Gorontalo.

Penelitian ini berlangsung selama 2 (dua) siklus. Tiap siklus terdiri dari 2-3 pertemuan. Alokasi waktu yang digunakan adalah 2 X 45 menit. Hasil penelitian yang diperoleh dianalisis menggunakan statistik deskriptif dan analisis secara kualitatif.

\section{HASIL PENELITIAN DAN PEMBAHASAN}

1. Pra Siklus

Sebelum diberikan tindakan, pendidik belum menggunakan aplikasi Waze dalam pembelajaran Mekanika Teknik. Pembelajaran masih didominasi oleh pendidik, dimana informasi berasal hanya dari 1 sumber, yaitu penjelasan dari pendidik. Hal tersebut memberikan dampak kepada peserta didik menjadi pasif dan tidak memiliki penyaluran kreatifitasnya. Hal tersebut dapat dilihat dari analisis deskriptif di bawah ini.

Minat belajar peserta didik sebelum diberikan tindakan menunjukan bahwa skor maksimum yang diperoleh siswa adalah 77 dari skor maksimum teoritik 100 , skor minimumnya adalah 48 dari skor minimum teoritik 0, didapat rentangan skor perolehan siswa adalah 29. Skor rata-rata 60,02, median 59,98 , modus 59,82, dan standar deviasi 9,48. Distribusi frekuensi skor minat belajar pra siklus dapat dilihat pada tabel dapat dilihat pada tabel dibawah ini.

\section{Tabel 1. Distribusi Frekuensi Minat Belajar Pra Siklus}

\begin{tabular}{llcccc}
\hline No. & & Skor & & Frekuensi Absolut & Frekuensi Relatif \\
\hline 1 & 48 & - & 53 & 7 & $26,9 \%$ \\
2 & 54 & - & 59 & 8 & $30,8 \%$ \\
3 & 60 & - & 65 & 4 & $15,4 \%$ \\
4 & 66 & - & 71 & 2 & $7,7 \%$ \\
5 & 72 & - & 77 & 5 & $19,2 \%$ \\
& Jumlah & & 26 & $100 \%$ \\
\hline
\end{tabular}


PEDAGOGIKA

Volume 10 (Nomor 2) 2019

Hal. 72-83

Kemampuan kognitif peserta didik sebelum diberikan tindakan menunjukan bahwa skor maksimum yang diperoleh siswa adalah 74 dari skor maksimum teoritik 100, skor minimumnya adalah 26 dari skor minimum teoritik 0, didapat rentangan skor perolehan siswa adalah 48. Skor rata-rata 61,52, median 61,58, modus 61,83, dan standar deviasi 15,55. Distribusi frekuensi skor kemampuan kognitif pra siklus dapat dilihat pada tabel di bawah ini.

Tabel 2. Distribusi Frekuensi Kemampuan Kognitif Pra Siklus

\begin{tabular}{cccccc}
\hline No. & & Skor & & Frekuensi Absolut & Frekuensi Relatif \\
\hline 1 & 26 & - & 35 & 2 & $7,7 \%$ \\
2 & 36 & - & 45 & 4 & $15,4 \%$ \\
3 & 46 & - & 55 & 3 & $11,5 \%$ \\
4 & 56 & - & 65 & 1 & $3,8 \%$ \\
5 & 66 & - & 75 & 16 & $61,5 \%$ \\
& Jumlah & & 26 & $100 \%$ \\
\hline
\end{tabular}

\section{Siklus I}

Siklus I (pertama) dilaksanakan dengan alokasi waktu 2 X @45 menit sebanyak 2 pertemuan. Proses pembelajaran pada siklus I (pertama) sudah memanfaatkan aplikasi/ software Waze. Perangkat lunak Waze dimanfaatkan dalam pembelajaran yang membahas topik tentang gerak (kecepatan, waktu, dan jarak). Peserta didik diberikan lembar kerja yang memuat tentang berbagai masalah yang harus dipecahkan sesuai dengan topik pelajaran. Peserta didik melakukan pengamatan dengan memanfaatkan perangkat lunak Waze secara berkelompok (3-4 orang per kelompok). Peserta didik mendiskusikan hasil pengamatannya kepada teman-teman yang lain dan juga kepada guru. Kemudian, peserta didik menyimpulkan dan mensimulasikan hasilnya.

Hasil pengamatan pada siklus I menunjukan bahwa skor maksimum 88 dari skor maksimum teoritik 100, skor minimumnya 56 dari skor minimum teoritik 0 , didapat rentangan skor perolehan siswa adalah 31. Skor rata-rata 69,87 , median 69,91, modus 70,51, dan standar deviasi 9,67. Distribusi frekuensi skor minat belajar pada siklus I dapat dilihat pada tabel di bawah ini.

Tabel 3. Distribusi Frekuensi Minat Belajar Siklus I

\begin{tabular}{cccccc}
\hline No. & & Skor & & Frekuensi Absolut & Frekuensi Relatif \\
\hline 1 & 56 & - & 62 & 9 & $34,6 \%$ \\
2 & 63 & - & 69 & 4 & $15,4 \%$ \\
3 & 70 & - & 76 & 6 & $23,1 \%$ \\
4 & 77 & - & 83 & 5 & $19,2 \%$ \\
5 & 84 & - & 90 & 2 & $7,7 \%$ \\
& Jumlah & & 26 & $100 \%$ \\
\hline
\end{tabular}


PEDAGOGIKA

Volume 10 (Nomor 2) 2019

Hal. 72-83

Kemampuan kognitif peserta didik pada siklus I menunjukan bahwa skor maksimum yang diperoleh siswa adalah 88 dari skor maksimum teoritik 100, skor minimumnya 36 dari skor minimum teoritik
0, didapat rentangan skor perolehan siswa 52. Skor rata-rata 67,55 , median 67,60 , modus 67,77, dan standar deviasi 15,80. Distribusi frekuensi skor kemampuan kognitif pra siklus dapat dilihat pada tabel di bawah ini.

\section{Tabel 4. Distribusi Frekuensi Kemampuan Kognitif Siklus I}

\begin{tabular}{cccccc}
\hline No. & & Skor & & Frekuensi Absolut & Frekuensi Relatif \\
\hline 1 & 36 & - & 46 & 5 & $19,2 \%$ \\
2 & 47 & - & 57 & 2 & $7,7 \%$ \\
3 & 58 & - & 68 & 2 & $7,7 \%$ \\
4 & 69 & - & 79 & 11 & $42,3 \%$ \\
5 & 80 & - & 90 & 6 & $23,1 \%$ \\
& Jumlah & & 26 & $100 \%$ \\
\hline
\end{tabular}

Pembelajaran pada siklus I belum memenuhi indikator pencapaian yang diharapkan, baik dari minat belajar maupun kemampuan kognitif yang diharapkan. Jumlah peserta didik yang memiliki memiliki minat belajar dan kemampuan kognitif yang diharapkan masih di bawah 75\%. Tetapi, terjadi peningkatan minat belajar dan kemampuan kognitif dari sebelum dilaksanakan siklus I.

Hasil pengamatan menunjukan bahwa, waktu yang dibutuhkan untuk proses verfication, dan generalization dirasakan kurang. Sehingga peserta didik belum mengeluarkan kemampuannya secara utuh. Terdapat peserta didik yang ragu-ragu dalam proses data collecting. Sehingga pada proses verfication dan generalization belum mampu menentukan hasil pengamatannya secara utuh (masih ragu-ragu).

Guru sebagai fasilitator dalam pembelajaran harus mampu membantu peserta didiknya dalam mengatasi masalah belajarnya. selain itu, guru juga harus cermat dalam menentukan alokasi waktu yang dibutuhkan sehingga peserta didik mampu menjelajahi setiap momen belajarnya.

\section{Siklus II}

Pelaksanaan pembelajaran siklus II (dua) dilaksanakan dengan alokasi waktu $2 \mathrm{X}$ @45 menit sebanyak 3 pertemuan. Pembelajaran siklus II merupakan perbaikan yang telah direkomendasikan pada tahapan refleksi siklus I. Pembelajaran siklus II masih memanfaatkan perangkat lunak Waze. Akan tetapi alokasi waktu pembelajaran ditambah menjadi 3 pertemuan. Selain itu, guru menerapkan metode diskusi secara individu pada peserta didik pada tiap tahapan pembelajaran.

Hasil pengamatan pada siklus II menunjukan bahwa skor minat belajar maksimum 88 dari skor maksimum teoritik 100, skor minimumnya 58 dari skor minimum teoritik 0, didapat rentangan 27. Skor rata-rata 76,78 , median 77,06 , modus 70,51, dan standar deviasi 9,67.

Distribusi frekuensi skor minat belajar pada siklus II dapat dilihat pada tabel di bawah ini. 
PEDAGOGIKA

Volume 10 (Nomor 2) 2019

Hal. 72-83

Tabel 5. Distribusi Frekuensi Minat Belajar Siklus II

\begin{tabular}{cccccc}
\hline No. & & Skor & & Frekuensi Absolut & Frekuensi Relatif \\
\hline 1 & 58 & - & 63 & 3 & $11,5 \%$ \\
2 & 64 & - & 69 & 4 & $15,4 \%$ \\
3 & 70 & - & 75 & 9 & $34,6 \%$ \\
4 & 76 & - & 81 & 5 & $19,2 \%$ \\
5 & 82 & - & 87 & 5 & $19,2 \%$ \\
& Jumlah & & 26 & $100 \%$ \\
\hline
\end{tabular}

Kemampuan kognitif peserta didik pada siklus II menunjukan bahwa skor maksimum yang diperoleh siswa adalah 91 dari skor maksimum teoritik 100, skor minimumnya 63 dari skor minimum teoritik
0 , didapat rentangan skor perolehan 27. Skor rata-rata 76,78, median 77,06, modus 78,06, dan standar deviasi 8,46. Distribusi frekuensi skor kemampuan kognitif siklus II dapat dilihat pada tabel di bawah ini.

Tabel 6. Distribusi Frekuensi Kemampuan Kognitif Siklus II

\begin{tabular}{cccccc}
\hline No. & & Skor & & Frekuensi Absolut & Frekuensi Relatif \\
\hline 1 & 63 & - & 68 & 5 & $19,2 \%$ \\
2 & 69 & - & 74 & 7 & $26,9 \%$ \\
3 & 75 & - & 80 & 6 & $23,1 \%$ \\
4 & 81 & - & 86 & 3 & $11,5 \%$ \\
5 & 87 & - & 92 & 5 & $19,2 \%$ \\
& Jumlah & & 26 & $100 \%$ \\
\hline
\end{tabular}

Pembelajaran pada siklus II telah memenuhi indikator keberhasilan yang diharapkan, baik minat belajar maupun kemampuan kognitif peserta didik. Jumlah peserta didik yang memiliki memiliki minat belajar dan kemampuan kognitif yang diharapkan sudah berada di atas angka 75\%. Terjadi peningkatan minat belajar dan kemampuan kognitif dari sebelum dilaksanakannya siklus II. Hasil pengamatan menunjukan bahwa, rekomendasi perbaikan yang telah ditentukan pada tahapan refleksi I telah dilaksanakan secara baik. Oleh karena itu, tindakan dilaksanakan hanya sampai pada siklus II. Berdasarkan deskripsi data hasil penelitian tindakan, dapat dikemukakan bahwa perangkat lunak Waze dapat diterapkan dalam pembelajaran Mekanika Teknik. Strategi pembelajaran yang digunakan adalah discovery learning yang terdiri dari stimulation, problem statement, data collecting, verification, dan generalization. Hal ini hanya berlaku pada siswa kelas X TP-2 SMK Negeri 3 Gorontalo. Perangkat lunak Waze yang diterapkan dalam pembelajaran Mekanika Teknik mampu meningkatkan minat belajar peserta didik. Selain itu, pembelajaran tersebut mampu meningkatkan kemampuan kognitif peserta didik siswa kelas X TP-2 SMK Negeri 3 Gorontalo. 
PEDAGOGIKA

Volume 10 (Nomor 2) 2019

Hal. 72-83

\section{KESIMPULAN}

Berdasarkan hasil penelitian dapat disimpulkan bahwa perangkat lunak Waze mampu meningkatkan kualitas proses pembelajaran Mekanika Teknik kelas X TP2 SMK Negeri 3 Gorontalo. Penerapan perangkat lunak yang tersedia di internet secara tepat akan membantu peserta didik dalam belajarnya. Perangkat lunak Waze dapat dijadikan pilihan metode pembelajaran dalam upaya meningkatkan kualitas proses pembelajaran Mekanika Teknik. Perangkat lunak Waze dapat diterapkan dalam pembelajaran Mekanika Teknik dalam strategi discovery learning, oleh sebab itu guru harus lebih kreatif lagi dalam memilih strategi pembalajaran sehingga minat belajar peserta didik menjadi lebih baik. Pembelajaran menggunakan perangkat lunak Waze terbatas pada tujuan tertentu saja. Oleh sebab itu, guru harus memiliki pemikiran yang out of the box sehingga mampu mengkreasikan setiap proses pembelajaran.

\section{REFERENSI}

Anderson, L. W., \& Krathwohl, D. R. 2010. Taxonomy for Learning, and Assessing: A Revision of Bloom's Taxonomy of Educational Objectives terjemahan Agung Prihantoro. Yogyakarta: Pustaka Pelajar.

Berpendidikan. (2015). Pengertian, Rumus dan Bunyi Hukum Newton 1,2,3 serta Contoh Soal Hukum Newton. Diambil kembali dari Berpendidikan. Rujukan Online Dunia Pendidikan: http://www.berpendidikan.com

Crain, W. (2007). Theories of Development: Concepts and Aplications terjemahan Yudi Santoso. Yogyakarta: Pustaka Pelajar.
Direktorat PSMK. (2013). Pembelajaran Berbasis Kompetensi dengan Pendekatan Saintifik. Jakarta: Direktorat PSMK, Kemendikbud.

Kemendibud. (2016). TIMSS Infografis. Diambil kembali dari Puspendik: http://puspendik.kemdikbud.go.id

Kemendikbud. (2016). Peraturan Menteri Pendidikan dan Kebudayaan Nomor 21 Tahun 2016 tentang Standar Isi Pendidikan Dasar dan Menengah. Jakarta: Kemendikbud.

Maimunah, M. (2013). Meningkatkan Hasil Belajar Siswa pada Pembelajaran IPA dengan Menggunakan Metode Discovery di SDN 16 Taruko Lintau Buo. Pedagogi Vol 13, No 1, 86-90.

Marfungatun.(2012). Peningkatan Motivasi Belajar Melalui Metode Pendekatan Inquiry. RADIASI, 97-100.

Mertler,C.A. 2011. Action Research, Mengembangkan Sekolah Memberdayakan Guru. Yogyakarta: Pustaka Pelajar.

Newby, T. J., \& et., al. 2011. Educational Technology for Teaching and Learning. Boston, MA: Pearson Education, Inc.

Pido, Z. 2010. Meningkatkan Hasil Belajar Peserta Didik pada Konsep Organisasi Kehidupan Melalui Model Kooperatif TIpe Discovery Learning. Jurnal Penelitian Pendidikan Ekonomi Vol. 2 No. 3.

Permendikbud No. 65 Tahun 2013 tentang Standar Proses Pendidikan Dasar dan Menengah. Standar Proses Pendidikan Dasar dan Menengah. Jakarta Pusat, DKI Jakarta, Republik Indonesia. 


\section{PEDAGOGIKA}

Volume 10 (Nomor 2) 2019

Hal. 72-83

Roblyer, M. D., \& Doering, A. H. (2013). Integrating Educational Technology into Teaching. New York: Pearson Education. Inc.

Smaldino, S. E., Lowther, D. L., \& Russel, J. D. (2012). Instructional Technology and Media for Learning Terjemahan Arif Rahman. Jakarta: Kencana.

SMK N 3 Gorontalo. (2016). Laporan Hasil Belajar Siswa SMK N 3 Gorontalo. Gorontalo: SMK N 3 Gorontalo.
Soetjipto, B. E. (2001). Inquiry as a Method of Implementing Active Learning. Jurnal Ilmu Pendidikan Vol 8, No 3, 191-2015.

Sugiyono. (2014). Metode Penelitian Kuantitatif, Kualitatif, dan R\&D. Bandung: Penerbit Alfabeta.

Widiyanto, \& Yogaswara, E. 2013. Mekanika Teknik. Jakarta: Kemendikbud. 